\title{
Study of variations in RhD holders of sickle cell disease patients of Amazon State, Brazil
}

\begin{abstract}
Introduction: Transfusion therapy is a challenge for patients with sickle cell disease, it develops antibodies against erythrocyte antigens, especially against the Rh system antigens, more frequently against $\mathrm{RhD}$ antigen, as this presents allelic variations in the RHD gene, resulting in structural changes in the protein, contributing to alloimmunization these individuals. However the frequency of these variants is not known in patients with sickle cell disease in the Brazilian Amazon.
\end{abstract}

Objective: In this study, our goal was to characterize the $\mathrm{RhD}$ variants and determine the relevance Transfusion in patients with Sickle Cell Disease in the State of Amazonas.

Materials and methods: We used 96 blood samples from patient's sickle, which were submitted to the RhD phenotype. Identification of RHD variant genotyping was performed by the microarray technique.

Results: A total of 96 samples, 36(37.5\%) presented discrepant results in serology for the detection of RhD antigen, and $12(33.3 \%)$ of these, characterized as variant $\mathrm{RhD}$. Among the 12 samples molecularly characterized as variant RhD, 4(33.33\%) DF5, followed by $3(25,00 \%)$ DIIIa, 2(16.66\%) DAU3, 1(8.33\%) DHMI, 1(8.33\%) DFV and $1(8.33 \%)$ DAR. However, the total of $96(100 \%)$ samples, two showed no exon 7 and the other did not show the intron 4 for multiplex PCR, however in serological tests showed normal results and the method of micro arrangements did not present RHD changes.

Discussion: This study is of great importance because it is the first results of detection of RhD variants in patients with sickle cell disease state of Amazonas, since our population is differentiated from the rest of Brazil. Is important to mention, it was possible to demonstrate a higher frequency of DF5 variant in our sickle patients, this also contrasts with the world literature, since DF5 variant is more frequent in Caucasians.

Conclusion: We emphasize the importance of characterization of $\mathrm{RhD}$ variants, in this population, as we can demonstrate significant results and that had not been described in the literature, making it clear techniques involving molecular biology increase transfusion safety and guarantee reliable results for the detection of erythrocyte antigens variants.

Keywords: genotyping, immuno-hematology, red cells, erythrocyte, RhD

\author{
Volume 5 Issue 4 - 2017
}

\author{
Lucianna Correa Tezza,' Edalton César \\ Sanguino,' Katiane Santos Gomes,' Sérgio \\ Roberto Lopes Albuquerque ${ }^{1,2}$ \\ 'Fundacao de Hematologia e Hemoterapia do Amazonas, Brasil \\ ${ }^{2}$ Universidade Federal do Amazonas, Brasil
}

\begin{abstract}
Correspondence: Sérgio Roberto Lopes Albuquerque, Fundacao de Hematologia e Hemoterapia do Amazonas, Hemocentro do Amazonas,-HEMOAM Avenida Constantino Nery, 4397, chapada, 69050-002. Manaus-AM,Bloco D, sala 10 Manaus, Brasil, Tel +5592991769493,

Email sergiorlalbuquerque@gmail.com
\end{abstract}

Received: July 24, 2017 | Published: November 01, 2017

\section{Introduction}

Transfusion therapy is a major challenge for patients with sickle cell disease, as these individuals have a high frequency of alloimmunization resulting from the development of antibodies to erythrocyte antigens, which the majority are formed with specificity against the $\mathrm{Rh}$ system antigens, ${ }^{1,2}$ this is because there are several genetic variations in $R H$ genes in sickle cell patients and are associated with alloimmunization $\mathrm{Rh},{ }^{3}$ though seemingly incompatible transfusions for the Rh system antigens. So the Rh system can be considered the largest and most polymorphic of all blood group systems, ${ }^{4}$ because of their immunogenicity of its antigens and be directly involved in post transfusion hemolytic reactions in autoimmune hemolytic anemia and especially in hemolytic disease. ${ }^{5}$ It may also be involved in a greater susceptibility of blood transfusions in individuals with sickle cell disease, triggering serious clinical consequences, such as post hemolytic transfusion reaction, antibody formation and destruction of autologous red blood cells.
Of the 54 antigens that form the Rh system, of which the most relevant are the antigens: $\mathrm{RhD}, \mathrm{C} / \mathrm{c}, \mathrm{E} / \mathrm{e}$, that among these the most important from a clinical point of view is the $\mathrm{RhD}$ antigen due to its high immunogenicity. ${ }^{6}$ The genes that form the Rh system are the $R H D$ gene encoding the $\mathrm{RhD}$ antigen and $R h C E$ gene, which encodes the antigens $\mathrm{C} / \mathrm{c}$ and E/e. ${ }^{6}$ The elucidation of the molecular basis of the Rh system is extremely important for patients with Sickle Cell Disease, as gene rearrangements, point mutations and deletions are responsible for numerous peptide variations in $\mathrm{RhD}$ antigens and RhCE.

In Brazil Castilho et al. ${ }^{7}$ demonstrate a high frequency of DIIIa variants and DAR, in patients with sickle cell anemia associated with Rhesus alloimmunization although apparently compatible for transfusion antigens of the Rh system. ${ }^{7}$ However individuals who express these variants are phenotype with $\mathrm{RhD}$ positive, but develop anti-D, lead to decreased survival of erythrocytes, because such individuals become dependent blood transfusion and higher 
risk alloimmunization. These results indicate the serological typing of red blood cells cannot distinguish between variant gene products $\mathrm{RhD}$, resulting in a later alloimmunization and a greater commitment survival of erythrocytes, once these patients have already changed the erythroid series sickle shaped and is also associated with changes in $\mathrm{Rh}$ protein ${ }^{8,9}$ and are expressed in them a greater amount of adhesion molecules and immunoglobulins, ${ }^{10,11}$ It may be associated with an increased susceptibility for transfusion in these individuals.

Erythrocytes with some form of altered expression of the RhD antigen are not hardly found in routine blood transfusion, there are an estimated $1 \%$ to $2 \%$ of Caucasians which have RHD alleles coding for weak $\mathrm{RhD}$ antigens am partial $\mathrm{RhD}$, which is the highest frequency in African ethnic individuals. ${ }^{12}$ By the fact these studies demonstrate that the $\mathrm{RhD}$ antigen variants in patients with sickle cell disease patients are diverse and are also associated with Hiperhemólise Syndrome ${ }^{13}$ which is constituted by a alloimmunization complication reported after blood transfusion, leading to decrease in hemoglobin and reticulocytosis, which results in the destruction of autologous and allergenic red blood cells in sickle cell patients, thus increasing the severity of existing pathophysiology of this disease, caused by chronic anemia caused after administration of red blood cells in these patients. ${ }^{14,15}$

Considering these data we saw that the $\mathrm{RhD}$ antigen variants might be not only involved the alloimmunization, but also the indication of blood transfusion in these individuals, but there are not many studies explaining an association of these variants with reduced lifetime of red blood cells, this reason suggests that patients carriers of sickle RhD variants may be contributing to an increased number of transfusions in these individuals. This demonstrates the high importance of characterization of the $\mathrm{RhD}$ variants in our study population, since do not yet exist data on the frequency of these variants in patients with sickle cell disease in the state of Amazonas.

\section{Materials and methods}

Were studied 96 samples of patients with Sickle Cell Disease State of Amazonas (heterozygous and homozygous for hemoglobin S), multiple transfusions or not. All patients agreed to participate in this study, signing a consent form Clarified approved by the Committee of Ethics is in the Amazon Blood Bank Research. The samples used were 128patients carriers of sickle cell disease treated at the Hospital Foundation of Hematology of the Amazon. Where all samples were subjected to the RhD phenotype techniques RHD genotyping technique by "micro-array".

\section{Serological study}

The RhD phenotyping was performed for 96 samples using the classic technique of hemagglutination tube, using the anti-D IgG class reagents clone MS26 and anti-IgM class D clone MS201 (Fresenius Kabi, Itapecerica da Serra, SP Brazil). Samples that were negative (no agglutination) in direct phenotyping for anti-RhD IgG and IgM were subjected to the test tube D weak. It was used for this test Human globulin (Fresenius Kabi, Itapecerica da Serra, SP Brazil) and the class of anti-D reagent IgG clone MS26 (Fresenius Kabi, Itapecerica da Serra, SP Brazil), where the presence or not was observed agglutination. Phenotyping for the CDE antigens was analyzed by hemagglutination technique tube. Were subjected to this test the samples showed negative for the weak D test, for study Ballas et al. ${ }^{16}$ and Judd et al. ${ }^{17}$ demonstrated, individuals with Del phenotype generally exhibit the antigen and $\mathrm{C}$ / or antigen of $\mathrm{E}$, therefore $\mathrm{RhD}$ negative individuals to test positive for anti-CDE may be a likely Del. This reagent detects the antigens $\mathrm{C}, \mathrm{D}$ and $\mathrm{E}$ of the Rh system.

\section{Molecular tests}

The DNA was extracted from the whole blood by phenol chloroform technique using a commercial kit Brazol TM LAC Biotechnology. The concentration and the quality of all the DNAs were measured with a NanoDrop spectrophotometer model 2000c (Thermo Scientific, Waltham, MA, USA). As the objective of this study was to describe the frequency of $R H D$ variants we used the Bead chip RHD kit, which uses 35 markers associated with allelic alterations RBD. This assay was performed using $2 \mu \mathrm{L}$ of each DNA sample with a concentration 20 to $70 \mathrm{ng}$ DNA, being used the protocol according to the manufacturer. It was used the technique microarrays, that uses a multiplex PCR that does simultaneous amplification of several DNA fragments where polymorphisms occur, By means of oligonucleotide probes deposited on a glass plate (glass, silica or other supports) that, when hybridized with target DNA fluoresce. The emitted fluorescence is detected and interpreted by an automated system capable of evaluating the fluorescence intensity and provide results that are easily viewed through graphs or tables genotypes. This technique has an excellent allelic discrimination, reduction of isolated procedures and their results are fully automated. ${ }^{18,19}$ And for presenting satisfactory results, because the technology "microarray" can be used to manage monitoring and control of transfusion of sickled patients and other patients multiple transfusions, as it allows a more accurate determination of blood units compatible to prevent alloimuzations, and potential hemolytic reactions and also to identify polymorphisms that serologic technique is not able to detect. ${ }^{18-21}$

\section{Results}

All samples were submitted to RhD phenotyping using anti-D reagent and IgG anti-D IgM, produced from clones mentioned in the methodology of this study. In these tests we found different results with discrepant intensities in the reading of agglutination ${ }^{22}$ as the following example: 4 crosses at a second reactant and the other crosses. The results of these discrepant and not discrepant fenotipagens are shown in Table 1 . Among the 36 phenotyping with discrepant results, only $12(33.3 \%)$ samples were confirmed as variant $\mathrm{RhD}$. However found in this study, 01 samples of variant $\mathrm{RhD}$ without discrepancy in the $\mathrm{RhD}$ phenotyping as shown in Table 2 . Still we found 2 samples that we classified as indeterminate, as had normal phenotyping, but in molecular biology using multiplex PCR, where one did not present the exon 7 and the other did not submit the intron 4, but to accomplish the PCR by the method of micro arrangements RHD showed no changes. The genotyping were performed for the RHD gene, using the micro array technique "micro-array", which uses a multiplex PCR that does the simultaneous amplification of several DNA ${ }^{23,24}$ fragments where polymorphisms occur, for a means of oligonucleotide probes deposited on a glass plate (glass, silica or other supports) which, when hybridized with target DNA fluoresce.

Table I Discrepancies detected in the serological reaction between the Anti$\mathrm{RhD}$ reagents of $\lg \mathrm{g}$ and $\lg M$ class

\begin{tabular}{lllll}
\hline Patients & \multicolumn{2}{c}{ Discrepant } & \multicolumn{2}{c}{ No discrepancies } \\
\hline $\mathrm{n}$ & $\mathrm{n}$ & $\%$ & $\mathrm{n}$ & $\%$ \\
96 & 36 & 37,5 & 60 & 62,5 \\
\hline
\end{tabular}


Table $2 \mathrm{RhD}$ variants and their serological reactions

\begin{tabular}{llll}
\hline Variants RHD & $\begin{array}{l}\text { Discrepancies } \\
\text { IgG e IgM }\end{array}$ & No discrepancies & Overall \\
\hline DIlla & 03 & 00 & 03 \\
DAU & 02 & 00 & 02 \\
DHMi & 01 & 00 & 01 \\
DAR & 00 & 01 & 01 \\
DF5 & 05 & 00 & 05 \\
DFV & 01 & 00 & 01 \\
Undetermined & - & 02 & 04 \\
\hline
\end{tabular}

For facilitate viewing of frequency of transfusions and presence of $\mathrm{RhD}$ variants, we conduct the following number of transfusions cuts, as shown in Table 3. It can be observed in Table 3 the frequency of $61.53 \% \mathrm{RhD}$ embodiment the cutting with frequency of $17-33$ transfusions. And 1patient who received more than 33 transfusions were not found $\mathrm{RhD}$ variants. Our results demonstrate that among the variants identified in our molecular tests, the DIIIa variant was the most frequent of the 96 samples analyzed within the range of $0-16$ transfusions, as shown in Table 4. Our results also demonstrate that only $1(7.69 \%)$ sample characterized as weak D type 5 , of $13(100 \%)$ of all variants were found in the range 34-60 transfusions. In Table 5 is demonstrated an analysis of the number of transfusions, age, presence of weak D type 5 variants. Of patients with variant $\mathrm{RhD}$, only the sample 152 showed anti-D antibody.

Table $3 \mathrm{RhD}$ variants in sickle cell patients according to the frequency of transfusions

\begin{tabular}{llllll}
\hline \multirow{2}{*}{ Frequency of transfusion } & \multicolumn{2}{c}{ Patients } & \multicolumn{2}{c}{ Variant RhD } & p \\
\cline { 2 - 5 } & $\mathbf{n}$ & $\%$ & $\mathbf{n}$ & $\%$ & value \\
\hline $0-16$ & 55 & 57,29 & 4 & 30,07 & \\
$17-33$ & 38 & 39,58 & 8 & 61,53 & \\
$34-60$ & 3 & 3,12 & 1 & 7,69 & \\
& 96 & 100,0 & 13 & 100,0 & 0,4236 \\
\hline
\end{tabular}

Table $4 \mathrm{RhD}$ variants found in different ranges transfusion

\begin{tabular}{|c|c|c|c|c|c|c|}
\hline RhD Variant & $\begin{array}{l}\text { Transf. } \\
0-16\end{array}$ & $\begin{array}{l}\text { \%Line } \\
\text { \%Column }\end{array}$ & $\begin{array}{l}\text { Transf. } \\
\text { 17-33 }\end{array}$ & $\begin{array}{l}\text { \% Line } \\
\text { \%Column }\end{array}$ & Total & $\%$ \\
\hline DIlla & 03 & $\begin{array}{l}100,00 \\
60,00\end{array}$ & - & - & 03 & $\begin{array}{l}100,00 \\
25,00\end{array}$ \\
\hline DHMi & - & - & 01 & $\begin{array}{l}100,00 \\
14,28\end{array}$ & 01 & $\begin{array}{l}100,00 \\
8,33\end{array}$ \\
\hline DAU3 & 01 & $\begin{array}{l}50,00 \\
20,00\end{array}$ & 01 & $\begin{array}{l}100,00 \\
14,28\end{array}$ & 02 & $\begin{array}{l}50,00 \\
16,66\end{array}$ \\
\hline DFV & - & - & 01 & $\begin{array}{l}100,00 \\
14,28\end{array}$ & 01 & $\begin{array}{l}100,00 \\
8,33\end{array}$ \\
\hline DF5 & 01 & $\begin{array}{l}20,00 \\
20,00\end{array}$ & 03 & $\begin{array}{l}75,00 \\
42,85\end{array}$ & 04 & $\begin{array}{l}57,14 \\
33,33\end{array}$ \\
\hline DAR & - & - & 01 & $\begin{array}{l}100,00 \\
14,28\end{array}$ & 01 & $\begin{array}{l}100,00 \\
8,33\end{array}$ \\
\hline Total & $\begin{array}{l}05 \\
10\end{array}$ & $\begin{array}{l}41,66 \\
100,0\end{array}$ & $\begin{array}{l}07 \\
14\end{array}$ & $\begin{array}{l}58,33 \\
100,0\end{array}$ & 12 & $\begin{array}{l}100,00 \\
100,00\end{array}$ \\
\hline
\end{tabular}

Table 5 Frequency of transfusions Dla variants, DAR, DHMI, DAU3, DFV and weak D type 5

\begin{tabular}{llll}
\hline $\begin{array}{l}\text { Frequency of } \\
\text { transfusions }\end{array}$ & $\begin{array}{l}\text { Age of the } \\
\text { patient }\end{array}$ & $\begin{array}{l}\text { RhD } \\
\text { variant }\end{array}$ & $\begin{array}{l}\text { Presence of } \\
\text { anti-RhD }\end{array}$ \\
\hline 9 & 7 & DIlla & Neg \\
9 & 18 & DIlla & Neg \\
16 & 17 & DIlla & Neg \\
21 & 27 & DAU3 & Neg \\
3 & 3 & DAU3 & Neg \\
18 & 54 & DAR & Neg \\
18 & 12 & DHMi & Neg \\
41 & 42 & DF5 & POS \\
9 & 9 & DF5 & Neg \\
24 & 8 & DF5 & Neg \\
20 & 13 & DF5 & Neg \\
30 & 61 & DF5 & Neg \\
18 & 28 & DF5 & Neg \\
\hline
\end{tabular}

\section{Discussion and conclusion}

This study is very important because it is the first results of detection of $\mathrm{RhD}$ variants in patients with Sickle Cell Disease State of Amazonas, as it our population is differentiated from the rest of the country. According to Brazilian Institute of Geography and Statistics, our population composed mainly of white, mixed race and indigenous. According to Noizat et al., ${ }^{25} \mathrm{RH}$ variants in patients with sickle cell disease are numerous, and she studied in the African-Caribbean individuals, associated with multiple transfusions alloimmunization in patients. ${ }^{25}$ This because the main therapy for these patients is the blood transfusion, which makes them a prospective risk for possible alloimmunization. Noizat also demonstrated that five main blood group antigens that may cause alloimmunization are respective antigens $(\mathrm{D}, \mathrm{C}, \mathrm{E}, \mathrm{c}, \mathrm{e})$. Is there genetic variation in these antigens caused by mutations caused by hybrid alleles, of which the most clinically relevant is called partial $\mathrm{RhD}$ variant. ${ }^{25}$ Corroborating Noizay study, Chou and Westhoff have shown that variants of the $\mathrm{RhD}$ gene are of great relevance in transfusion medicine for sickle cell patients, they have shown that $22 \%$ of patients with sickle cell disease african Americans have this hybrid gene, resulting in changes in some epitopes of the RhD protein, leading these patients to be phenotyped 
as normal $\mathrm{RhD}$ positive and, though on receiving $\mathrm{RhD}$ positive red cells, develop Anti-D Antibodies.

Agreeing with study Noizat, Westhoff and colleagues studied serologically and molecularly 39 African-American patients, of which the study serologic $18(46.15 \%)$ had anti-D. ${ }^{26}$ Corroborating work Westhoff et al. ${ }^{26}$ and Castilho et al. ${ }^{27}$ also demonstrated that in african-Brazilians there is a high frequency of variant DIIIa and DAR, too suggesting a high risk individuals such alloimmunization, leading to a reduction of the lifetime of the erythrocytes in circulation. ${ }^{27}$ Unlike Westhoff et al. ${ }^{26}$ and Castilho et al. ${ }^{27}$ our results show a higher frequency of DF5 variant in patients with sickle cell disease, This also contrasts with the literature, since DF5 variant is more frequent in Caucasians. ${ }^{28}$ Our study also diverges with Müller et al., ${ }^{28}$ where it was demonstrated that among the variants of the weak D type, the most frequent are respectively variants weak D types 1,2,3,4 and 5, being less frequent variant DF5 of these cited and still, In the same study it was not reported any alloimmunization for anti-D in patients characterized with some of these variants. ${ }^{28-30}$ However in our study, 1 sample $(20 \%)$ of $5(100 \%)$ characterized with DF5, developed anti-D.

The weak D variants may occur because amino acid substitutions of different types of weak $\mathrm{RhD}$ are located in the transmembrane and intracellular segments of the RhD protein. On the other hand we suggest that other factors may also be contributing to this constant hemolysis. This is because erythrocyte membrane is composed of structural proteins crucial for normal morphology of the erythrocytes. Among these we can cite the ankyrin, CD47 and spectrin-binding protein 4.2, which are connected to the Rh complex as demonstrated Nicolas et al. ${ }^{8}$ Therefore changes in the interactions between these proteins located in the lipid bilayer and the underlying components that make up the erythrocyte cytoskeleton, such as Rh protein, they can also lead to decreased life time of erythrocytes in peripheral blood. Corroborating Nicolas et al. ${ }^{8}$ study, Ballas et al. ${ }^{14}$ provide evidence that the absence of the $\mathrm{Rh}$ protein (Rhnull) can result in hemolytic anemia called ovalocitosis, due to the fragility caused by the absence of the $\mathrm{Rh}$ protein result in changes 4.2 binding protein comprising the erythrocyte cytoskeleton.

Among the 54 antigens of the RH system currently described by the International Society of Blood Transfusion, the $\mathrm{RhD}$ antigen, and is more immunogenic also it is important in the interaction with the cytoskeleton of erythrocytes. Therefore, we suggest that changes in the $\mathrm{RhD}$ antigen may influence the greater fragility of red blood cell membrane further reducing its life time in circulation, suggesting that patients with sickle cell patients these variants may be more susceptible to a greater number of transfusions. The difference between red blood cells that present partial $\mathrm{RhD}^{31}$ variants, which have altered epitopes, from those that have the antigenic density lower (Del and RhD weak) is important to avoid possible alloimuzations. Whestoff ${ }^{32}$ demonstrated that due to limitations on reagents used hemagglutination technique to differentiate $\mathrm{RhD}$ variants, many patients have produced anti-D because they were considered positive $\mathrm{RhD}$.

Moreover, patients considered as $\mathrm{RhD}$ negative in serological study, due to the low antigen density, may have the RHD gene, these being characterized as variant $\mathrm{D}$ weak. We carried out the serological and molecular study of $96(100 \%)$ of patients with sickle cell disease treated at HEMOAM, of which $36(37.50 \%)$ presented results of a discrepancy between the anti-D $\operatorname{IgM}$ reagents and anti-D $\operatorname{IgG}$, and among these only $12(33.33 \%)$ were characterized molecularly as $\mathrm{RhD}$ variants. Corroborating study by Credidio, ${ }^{33}$ in which was used the same hemagglutination technique tube, our results also showed differences among the anti-D IgM reagents and anti-D IgG in the samples characterized as DF5 variants. For samples characterized as HDMI, DAR, day and DAU3 also obtained discrepant results in serology, which may result in a transfusion normal $\mathrm{RhD}$ positive red blood cells, for a patient who has some changes in the $\mathrm{RhD}$ protein epitopes, once if the transfusion routine is phenotyped as normal $\mathrm{RhD}$ positive, leading him to a possible alloimmunization. Our results with previous publications of the literature clearly shows that serologic techniques should be associated with molecular biology, to thereby considerably increase transfusion safety due to a better characterization of the $\mathrm{RhD}$ antigens for dependent patients from transfusion therapy and still seeks greater insight into the interactions of this antigen with other proteins crucial for the normal stability of the erythrocyte.

\section{Acknowledgements}

None.

\section{Conflict of interest}

The author declares no conflict of interest.

\section{References}

1. Rosse W, Gallagher D, Kinney T, et al. Transfusion and alloimmunization in sickle cell disease. The cooperative study of sickle cell disease. Blood. 1990;76(7):1431-1417.

2. Aygun B, Padmanabhan S, Paley C, et al. Clinical significance of RBC alloantibodies and autoantibodies in sickle cell patients who received transfusions. Transfusion. 2002;42(1):37-43.

3. Noizat Pirenne F, Lee K, et al. Rare RHCE phenotypes in black individuals of Afro-Caribbean origin: identification and Transfusion safety. Blood. 2002;100(12):4223-4231.

4. Huang $\mathrm{CH}$. Molecular insights into the $\mathrm{Rh}$ protein family and associated antigens. Curr Opin Hematol. 1997;4(2):94-103.

5. Levine P, Stetson RE. An unusual case of intra-group agglutination. JAMA. 1939;113(2):126-127.

6. Agre P, Cartron JP. Molecular biology of the Rh antigens. Blood. 1991;78(3):551-563.

7. Castilho L, Rios M, Rodrigues A, et al. High frequency of partial DIIIa and DAR alleles found in sickle cell disease patients suggests increased risk of alloimmunization to RhD. Transfus Med. 2005;15(1):49-55.

8. Nicolas V, Mouro Chanteloup I, Lopez C, et al. Functional interaction between $\mathrm{Rh}$ proteins and the spectrin-based skeleton in erythroid and epithelial cells. Transfus Clin Biol. 2006;13(1-2):23-28.

9. Bruce LJ, Ghosh S, King MJ, et al. Absence of CD47 in protein 4.2-deficient hereditary spherocytosis in man: an interaction between the Rh complex and the band 3 complex. Blood. 2001;100(5):1878-1885.

10. Galili U, Clark MR, Shohet SB. Excessive binding of natural anti-alphagalactosyl immunoglobin $\mathrm{G}$ to sickle erythrocytes may contribute to extravascular cell destruction. $J$ Clin Invest. 1986;77(1):27-33.

11. Green GA. Autologous IgM, IgA, and complement binding to sickle erythrocytes in vivo. Evidence for the existence of dense sickle cell subsets. Blood. 1993;82(3):985-992.

12. Daniels G, Faas B, Green C, et al. The VS and V blood group polymorphisms in Africans: a serologic and molecular analysis. Transfusion. 1998;38(10):951-958.

13. Chou ST, Westhoff CM. Molecular biology of the Rh system: clinical considerations for transfusion in sickle cell disease. Hematology Am Soc Hematol Educ Program. 2009;2009(1):178-184. 
14. Ballas SK, Marcolina MJ. Hyperhemolysis during the evolution of uncomplicated acute painful episodes in patients with sickle cell anemia. Transfusion. 2006;46(1):105-110.

15. Talano JA, Hillery CA, Gottschall JL, et al. Delayed hemolytic transfusion reaction/hyperhemolysis syndrome in children with sickle cell disease. Pediatrics. 2003;111(6 Pt 1):e661-e665.

16. Ballas SK, Clark MR, Mohandas N, et al. Red cell membrane and cation deficiency in Rh null syndrome. Blood. 1984;63(5):1046-1055.

17. Judd WJ, Johnson ST, Storry J. Judd's methods in immunohematology. 3rd ed. USA: AABB press; 2008

18. Yasuda H, Ohto H, Sakuma S, et al. Secondary anti-D immunization by Del red blood cells. Transfusion. 2005;45(10):1581-1584

19. Wagner T, Kormoczi GF, Buchta C, et al. Anti- D immunization by DEL red blood cells. Transfusion. 2005;45(4):520-526.

20. Chomczynski P. A reagent for the single-step simultaneous isolation of RNA, DNA and proteins from cell and tissue samples. Biotechniques. 1993;15(3):532-537.

21. Petrik J. Microarray technology: the future of blood testing? Vox sanguinis. 2001;80(1):1-11.

22. Anstee DJ. Goodbye to agglutination and all that? Transfusion. 2005;45(5):652-653.

23. Hashmi G, Shariff T, Seul M, et al. A flexible array format for large-scale, rapid blood group DNA typing. Transfusion. 2005;45(5):680-638.

24. Hashmi G, Shariff T, Zhang Y, et al. Determination of 24 minor red blood cell antigens for more than 2000 blood donors by high-throughput DNA analysis. Transfusion. 2007;47(4):736-747.
25. Noizat Pirenne F. Relevance of blood groups in transfusion of sickle cell disease patients. Comptes rendus biologies. 2013;336(3):152-158.

26. Westhoff CM, Vege S, Halter Hipsky C, et al. DIIIa and DIII Type 5 are encoded by the same allele and are associated with altered RHCE* ce alleles: clinical implications. Transfusion. 2010;50(6):1303-1311.

27. Castilho L, Rios M, Rodrigues A, et al. High frequency of partial DIIIa and DAR alleles found in sickle cell disease patients suggests increased risk of alloimmunization to RhD. Transfus Med. 2005;15(1):49-55.

28. Müller TH, Wagner FF, Trockenbacher A, et al. PCR screening for common weak D types shows different distributions in three Central European populations. Transfusion. 2001;41(1):45-52.

29. Wagner FF, Frohmajer A, Ladewig B, et al. Weak D alleles express distinct phenotypes. Blood. 2000;95(8):2699-2708.

30. Wagner FF, Gassner C, Müller TH, et al. Molecular basis of weak D phenotypes. Blood. 1999;93(1):385-393.

31. Gahmberg CG, Karhi KK. Association of Rho(D) polypeptides with the membrane skeleton in Rho(D)-positive human red cells. J Immunol. 1984;133(1):334-337.

32. Westhoff $\mathrm{CM}$. The $\mathrm{Rh}$ blood group system in review: a new face for the next decade. Transfusion. 2004;44(11):1663-1673.

33. Credidio DC. Variantes do antígeno RhD: estudo sorológico e molecular. Repositório da Produção Científica e Intelectual da Unicamp, Brazil; 2010. p. 1-114. 